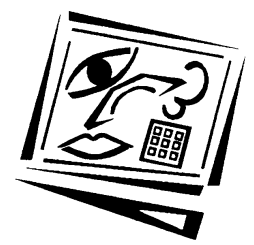

\title{
Factors influencing perceived usefulness of wikis for group collaborative learning by first year students
}

\author{
Zixiu Guo and Kenneth John Stevens \\ The University of New South Wales
}

\begin{abstract}
This study reports the findings of an investigation of the factors influencing the use and usefulness of wikis in an introductory, undergraduate information systems course. Informed by the media choice, technology acceptance model from information systems research, and group collaborative learning research from the education literature, a survey instrument was developed and administered across the entire course. The study found that wiki use was influenced by the student's prior expertise with wikis, with their perceived usefulness of wikis being strongly influenced by their teachers' attitudes towards the technology, and the ease of access to the wikis. The students' overall attitude towards wikis was largely influenced by the extent to which they saw wikis as helping with their assignment work, and their intention to use wikis in the future was driven by their perception of wiki's usefulness. The paper concludes with an outline of the lessons learned from the study and recommendations for instructors who are thinking of using wikis in their teaching.
\end{abstract}

\section{Introduction}

The use of the Web 2.0 technologies in teaching and learning in higher education has attracted considerable attention in recent years and many course coordinators have sought to utilise these technologies in their courses (Cole, 2009; Guo, Zhang \& Stevens, 2009). Of these technologies, wikis have been one of the most popular (Elgort, 2007; Jones, 2007). Wiki (which means 'quick' in Hawaiian) was originally developed by Cunningham and further refined by Leuf and Cunningham as a "freely expandable collection of interlinked Web pages, a hypertext system for storing and modifying information - a database where each page is easily editable by any user with a formscapable Web browser client" (Leuf \& Cunningham, 2001, p14). As a social networking adaptive technology that "emphasises a more task-oriented collaborative editing of content and development of 'collective' interlinked knowledge" (Duffy \& Bruns, 2006, p.37), and because of "their very low technological barriers, yet very rich and flexible functionality" (McMullin, 2005, p.72), wikis have shown great potential in enhancing collaborative learning (Elgort, Smith, \& Toland, 2008; Jones, 2007; Ramanau \& Geng, 2009).

Due to its novelty as a teaching and learning tool, academic interest in wikis is only recent and research into its application in the teaching environment is somewhat sparse (Parker \& Chao, 2007). In particular, "research that addresses pedagogical benefits and pitfalls of using wikis as a collaborative learning tool is still rather limited" (Elgort, et al., 2008, p.195) and more empirical studies are required to further examine the use of wikis to support collaborative learning in blended learning environments (Ramanau \& Geng, 2009). 
This study seeks to redress this shortfall through an investigation of the introduction of wikis into an undergraduate 'Information Systems in Business' course taken by business and information systems students at the University of New South Wales. Through a survey conducted within this class, this study sought to understand the factors that influenced the students' use and perceptions regarding wiki's usefulness and their intention to use wikis in future collaborative work. Specifically, this study aimed to address the following research questions:

1. What factors influence the use of wikis for group collaboration?

2. What factors influence the usefulness of wikis for group collaboration?

3. What factors influence students' intentions to use wikis in group collaboration in future courses?

The next section describes the characteristics of group collaborative learning. The characteristics of wiki and its impacts on learning are then outlined and are followed by an overview of the factors that have been suggested to impact on effective use of wikis. The study context is then described, followed by the research method and the results. The paper concludes with an outline of the lessons learned from the study and recommendations for instructors who are considering the use of wikis in their teaching.

\section{Group collaborative learning}

Teamwork and collaborative learning have become key competencies for students in today's rapidly changing business environment (Elgort, et al., 2008). The teaching of teamwork and collaborative learning is also one of the Seven principles for good practice in undergraduate education (Chickering \& Gamson, 1987) and has become part of the graduate attributes of most universities, with many curriculums and class instructions now incorporating teamwork and collaborative learning in their course designs (O'Neil, Chuang \& Chung, 2003).

Collaborative learning "involves social processes by which a small group of students work together to complete an academic problem solving task designed to promote learning" (Alavi, 1994, p.161). As with prior studies (such as Roschelle \& Teasley, 1995; Stahl, Koschmann, \& Suthers, 2006), collaborative learning is seen as distinct from cooperative learning. According to Roschelle and Teasley (1995, p.70):

Cooperative work is accomplished by the division of labor among participants, as an activity where each person is responsible for a portion of the problem solving. We focus on collaboration as the mutual engagement of participants in a coordinated effort to solve the problem together.

In other words, cooperative learning actually takes place individually and coordination is only required when assembling partial results (Dillenbourg, Baker, Balye \& O'Malley, 1996), while collaborative learning occurs socially and is "a coordinated, synchronous activity that is the result of a continued attempt to construct and maintain a shared conception of a problem" (Roschelle \& Teasley, 1995, p.70).

The key success factors for collaborative learning include: positive interdependence of group members; supplementary guidance through active teacher participation, input, feedback, and corrections and sample materials; individual and group responsibility; confidence in completing the tasks; the nature of the task; and the distribution of 
control amongst students (Dillenbourg, et al., 1996; McMullin, 2005; Reinhold \& Abawi, 2006).

The collaborative learning approach is seen to have beneficial effects on learning (Stahl, et al., 2006) as it is more effective than traditional instructional methods in promoting student learning and academic achievement (Hiltz, Coppola, Rotter \& Turoff, 2000). It has also been shown to enhance learning through increasing student's engagement with subject matter (Schaffert, et al., 2006) and promoting critical thinking (Alavi, 1994), which leads to more interaction among students (Dewiyanti, BrandGruwel, Jochems \& Broers, 2007), increased feelings of connection with other students (So \& Brush, 2008), and enhanced student satisfaction with the learning experience (Dewiyanti, et al., 2007). The increased social interaction with group members during group collaboration also provides motivation for student participation and learning in group tasks (So \& Brush, 2008).

\section{Wiki characteristics and implications for learning}

As a piece of well-known social software, wiki has the following key characteristics (Duffy \& Bruns, 2006):

- A wiki is a website that allows a user to add content, which can be edited by any other users;

- Wikis can be personal, but are usually open to collaboration;

- Wikis involve the creation of documents without the need for technical knowledge of HTML;

- Wikis tend towards expressing ideas as relationships between pages, thus creating a network of interrelated topics;

- Wikis are a-temporal;

- Wikis track changes to pages and hence maintain a history of a page's development;

- Wikis encourage cross-linking and are dominantly spatial in structure; and

- Wikis provide a space where knowledge becomes networked but remains ephemeral in that it can be changed and mediated by the community.

Much of wiki's appeal lies in its support for web-based collaboration and knowledge management, and it is these functions that have made it attractive to educators. It has found widespread use in education in supporting collaborative activities (Raman, Ryan \& Olfman, 2005), project management (Xu, 2007), developing and maintaining software projects (Malani \& Dwyer, 2005), supporting writing instruction (Lamb, 2004), arranging information and sharing knowledge (Elgort, et al., 2008), online teaching and assessment (Bruns \& Humphreys, 2005), being designed into a learning sequence as an integrated component (Jones, 2007), and online collaboration in the elearning environment (Raitman, Augar \& Zhou, 2005).

\section{Factors affecting the effective use of wikis in learning}

Despite its apparent usefulness in group collaborative learning, the use of wikis in learning is not always successful (e.g., Choy \& Ng, 2007; Cole, 2009). Given the considerable benefits that wikis would appear to offer, it would seem very important to understand what influences the acceptance and use of wikis so that educators may improve the likelihood of success when introducing or refining the use of wikis in their courses. 
Within the Information Systems (IS) discipline, a significant body of research has evolved which examines the factors that influence users' acceptance and use of information technologies in both organisational and learning contexts. Both media choice and technology adoption models (TAM) have identified a combination of factors, such as technology and task characteristics, individual differences, technology experience, social influence, and technology self-efficacy as affecting technology choice (e.g. Davis, 1989; Rice \& Webster, 2002; Venkatesh \& Davis, 2000). As all of the participants involved in this study used the same wiki on the same assessment activity, it was only considered necessary to examine the impact of individual differences, technology experience, social influence, and technology self-efficacy on the student's use and perceptions of use of the wiki in accomplishing their group collaborative tasks.

\section{Individual differences}

Individual differences, such as age and gender, have been found to be important factors in the adoption and usage of information technologies (Gribbins, Hadidi, Urbaczewski \& Vician, 2007). Fulk (1993) posits that younger, better educated people should be more receptive to a new technology because they are less likely to be anxious about using it. Gefen and Straub (1997) found that women and men differ in their perceptions of email. Nachmias et al. (2000) found more boys than girls used the Internet, with no significant differences in the extent and modes of Internet use among different age groups, and Guo et al. (2008) demonstrated that gender had a significant impact on the use of Instant Messaging (IM), email, and telephone. In contrast, Zhang (2005) found that younger, better educated people believed the Internet to be more useful than others, but found no significant differences in the perceptions across gender.

\section{Technology related factors}

King and Xia (1997) found that an individual's specific experience with communication media affected their perceptions of media appropriateness, and the positive effects of the changes in learning experience were particularly salient for new media. Guo et al. (2008) also found that IM experience and preference for use in communication were related, especially where the receivers' attention or presence was required. Studies have also demonstrated that familiarity with a new technology was important in determining how people used the new technology (Guo, et al., 2008; Rice, 1993), with technology accessibility found to impact users' perceptions and use of a technology (Guo \& D'Ambra, 2009; McCreadiea \& Rice, 1999; Rice \& Shook, 1988). In this study, students' experience of using wikis, expertise in wikis, accessibility of the Internet and wikis, and other relevant technology experience were included to see if these factors impacted the way students perceived and used wikis in their learning.

\section{Technology self-efficacy}

Originating in social cognitive theory, self-efficacy is defined as "beliefs in one's capabilities to organise and execute the courses of actions required to attain designated types of performance (Bandura, 1986, p.391). It emphasises the importance of the judgments about what one can do with whatever skills one possesses, rather than what skills one has. In technology mediated environments, studies have found that an individual's technology self-efficacy (belief in one's ability to use the information technology) impacts their intention to use the technology (Compeau \& Higgins, 1995). In the technology mediated learning environment, technology self-efficacy was also found to have significant impact on students' adoption and use of technologies and learning performance (e.g. Ahmad, Basha, Marzuki, Hisham \& Sahari, 2010; Tsai, Tsai, 
\& Hwang, 2010). If students feel uncomfortable with the technologies that they use in their learning and do not feel confident in their ability to use the technology effectively, they may experience difficulty in their interactions with peers and instructors, and in the completion of their work. It would be expected that this should negatively affect their attitudes towards the use of the technology. It may also impact on their learning outcomes.

Instructor's impact

According to the social influence model of technology use (Fulk, Steinfield, Schmitz \& Power, 1987), social influences such as group norms and co-worker/ supervisor attitudes and behaviours can influence individuals' attitudes toward the use of new technologies. Studies have shown that social influence impacts technology use (Fulk, 1993; Rice \& Aydin, 1991). In the educational context, instructors' attitudes and behaviours toward technologies have been found to impact students' perceptions and use (Watson, 1998). For example, Webster and Hackley (1997) found that the instructor's attitude toward technology can significantly influence students' attitudes toward technology and e-learning. Kersaint et al. (2003) found that instructors who have positive attitudes toward technologies would feel more comfortable using them and more likely to incorporate them into their teaching. Similarly, Bullock (2004) found that instructors' attitudes toward technologies are the key enabling/disabling factor in students' adoption of technologies.

\section{Method}

\section{Study context}

This study was conducted in the course "Information Systems in Business", which is taught by the IS School, within the business faculty. The course is a standard 12 week course (being one quarter of a normal full time semester load) with approximately 300 students.

The course is compulsory for students pursuing an IS degree or IS major and an elective for students pursuing the business degree. It is very popular with students undertaking an accounting major because it is required for admission to the Australian Association of Certified Practicing Accountants.

The course has undergone a number of revisions to its content and teaching approach over recent years and in semester 2, 2009 involved 12 weeks of lectures and workshops. The lectures were a traditional $1 \mathrm{hr}$ slide based presentation by the lecturer-in-charge (LIC) to the whole course and the $2 \mathrm{hr}$ workshops were compulsory classes of up 25 students per class. The workshops involved both individual and group based activities for which students were expected to prepare, with the preparation and participation being assessed. The 13 separate workshop classes were spread across 5 tutors. Consistency across the 13 workshop classes was maintained through the use of a 'workshop guide', written by the LIC and senior tutor and discussed in the weekly tutors meeting. The assessment regime included: In-class Quizzes (10\%), Workshop Preparation Worksheets (10\%), Workshop Participation (10\%), Case study Assignment $(30 \%)$, and Final Examination $(40 \%)$. The groups for the assessable groupwork were made up of students from the same workshop, with students self-selecting groups.

The use of wikis was incorporated into the course in two ways. First, it was promoted among the students by the lecturer and tutors as a useful mechanism to assist with 
their studies. Second, it was incorporated into the assessment regime via its inclusion in the weekly group workshop assignment and the group case study assignment.

The weekly workshop assignment was worth $10 \%$ of the overall assessment (1\% per week $x 10$ weeks). Each week groups were required to use their wiki page to submit their answers to a set of questions. Tutors then accessed each group's page, graded answers and checked the contribution of the group members. The use of wikis in this component was mandatory as wikis were the only means by which answers could be submitted.

The case study assignment was worth $30 \%$ of the overall assessment and involved groups preparing a report about a provided case study. The assignment commenced in Week 6, with the submission of the case study report due in Week 11. The mandatory use of wikis in the case study assignment was limited to an initial 'brainstorming' exercise, but groups were strongly encouraged to continue the use of wikis throughout the assignment.

The wiki space for the course was provided by the University's IT group. The MoinMoin (Version 1.8.4) wiki was installed in a straightforward configuration that incorporated rudimentary version and access control. Administration of the wiki was undertaken by the senior tutor (who had some wiki experience).

An account was created for each student, with the usernames and passwords for the accounts being distributed in the first workshop. Instructions about logging on, security codes, page creation, and so on were also provided in the first workshop. Technical assistance and support was made available via an online 'Wiki Hotline', staffed by the senior tutor. A wiki page was created for each group with access to a group's wiki page provided via user accounts. Groups were free to create subsidiary pages as desired. Each workshop class was given a wiki page to which the students were encouraged to link their group and individual pages. Each tutor had access to the pages for the groups and students from their classes. The senior tutor and the LIC had access to all pages.

\section{Survey instrument design}

A survey instrument was developed to measure key independent and dependent variables of the study. The instrument comprised three sections.

The first section gathered demographic information about the students, such as age, gender, international or local student, and major. Technology related experience measures included: the quality and accessibility of their Internet connections, their experience and familiarity with the Internet and popular Web 2.0 technologies (Facebook, MySpace, blogs, and forums). Technology self-efficacy was measured by using a scale adapted from Compeau and Higgins (1995). After a principal component factor analysis followed by varimax rotation, a single factor was generated with a satisfactory reliability of .89 .

Section two asked questions about the use of wikis in general (outside the course) and section three sought information about the student's use of wikis in the course. Section three covered a broad range of areas, including questions concerning: 
- Easy of access to wikis during the course.

- Time taken to learn wikis.

- Perceived expertise with wikis at the beginning and the end of semester.

- The extent of usage of wikis throughout the semester.

- The usefulness of wikis in the completion of the assessment tasks.

- Future intention to use wikis.

- Overall attitude towards wikis.

In addition to the survey data, information about each tutor in regard to wikis was sought from the senior staff involved in the course. This information included a ranking of the tutor's experience for using wikis and their attitude towards wikis in this course. These rankings were judgemental and based on their interaction with and observation of the tutors over the semester.

The instrument was reviewed by colleagues and their feedback led to a number of improvements. The instrument was then piloted on a group of students (not currently undertaking the course) and their feedback was also used for a number of further improvements as well as gauging the time required to complete. The finalised survey instrument was seven pages long, inclusive of instructions and consent form, with an expected completion time of 15 minutes.

\section{Data collection procedure}

Permission to undertake the survey was sought from the LIC of the course. The weekly workshops were identified as the most appropriate forum in which to administer the survey. Access to these classes was arranged with the tutors.

The survey was administered to all students present in each of the 13 workshops during the first week of October (Week 11) by researchers not involved in the teaching of the course. Completed surveys were assigned a sequence number (which identified the workshop, but not the student). 205 useful surveys were collected, representing $71 \%$ of the students undertaking the course. A review of the sample's demographics against that of the course showed the sample to be representative of the course.

The surveys were found to be remarkably complete, with virtually all questionnaires collected being useful. The EM estimation method (Dempster, Laird \& Rubin, 1977) was used to replace the few missing data points on the few incomplete questionnaires. The data from the surveys was entered into SPSS version 17, with a sample of surveys checked against the entered data to ensure accuracy. The data collected and the data entry were considered to be of sufficient quality for analysis.

\section{Data analysis}

A stepwise regression analysis was used to identify the most useful independent variables in the data to answer the three research questions. First, the dependent variables regarding students' wiki usage and the perceived end of semester wiki expertise were examined against the key independent variables (gender, age, international or local, Internet accessibility, Internet quality, Internet experience, Facebook/MySpace experience, blog experience, forum experience, technology selfefficacy, past wiki experience, and initial wiki expertise). Second, the dependent variables for each of the perceived wiki usefulness variables were examined against the independent variables, which included the key independent variables mentioned 
above and the wiki usage variables. The usage variables were included because it was found that technology usage was related to students' perceptions of its usefulness (Hiltz, 1994). Third, the dependent variables of the overall attitude toward wiki and the intention to use it in the future were examined against all key independent variables, the wiki usage variables and perceived wiki usefulness variables.

\section{Results}

This section sets out the results of the data analysis. The demography and technology experience of the respondents are outlined first, followed by the results for each of the three research questions.

\section{Demographic and technology use experience}

Tables 1a-1d set out the demographics of the respondents as well as their technology experience. Almost all students were aged below 25. Two thirds of students were international students and 95\% of students were undertaking business degrees. Students reported that they could easily access a high quality Internet service. The average Internet experience was 8.9 years (Table 1b). In regard to Web 2.0 experience of the students (Table 1c), 93\% of students were familiar with Facebook or MySpace, approximately half of the students had used blogs and forums, and only $5 \%$ of students reporting no Web 2.0 experience. In regard to wikis, only $16 \%$ had experience creating and modifying content pages in wikis, hence the initial perceived wiki expertise was very low (Mean=2.39, on a scale of 1-5). The reported technology selfefficacy was very high, with local students being higher than international students (Table 1d).

Table 1a: Respondent demographics $(n=205)$

\begin{tabular}{|l|l|c|}
\hline \multirow{2}{*}{ Gender } & Male & $44.9 \%$ \\
\cline { 2 - 3 } & Female & $55.1 \%$ \\
\hline \multirow{3}{*}{ Sge } & $<=20$ & $63.4 \%$ \\
\cline { 2 - 3 } & $21-25$ & $35.6 \%$ \\
\cline { 2 - 3 } & $>25$ & $1 \%$ \\
\hline \multirow{2}{*}{ Student status } & International students & $67.8 \%$ \\
\cline { 2 - 3 } & Local students & $32.2 \%$ \\
\hline & Commerce/Economics (non-IS) & $94.6 \%$ \\
\cline { 2 - 3 } & IS and Computer Science & $4.4 \%$ \\
\cline { 2 - 3 } & Others & $1 \%$ \\
\hline
\end{tabular}

Table 1b: Internet experience

\begin{tabular}{|l|c|}
\hline \multicolumn{1}{|c|}{ Internet experience } & Mean (S.D.) \\
\hline $\begin{array}{l}\text { How easy is it for you to access the Internet? } \\
\text { (scale 1-5 from "Very difficult" to "Very easy") }\end{array}$ & 4.54 (0.76) \\
\hline How long have you been using the Internet (years)? & $8.91(2.53)$ \\
\hline $\begin{array}{l}\text { What is the quality of this Internet access? } \\
\text { (scale 1-5 from "Very poor" to "Very good") }\end{array}$ & $3.89(0.96)$ \\
\hline
\end{tabular}

\section{Wiki use}

Most respondents believed that they had an easy access to the course wiki website $($ Mean $=3.76$, S.D. $=1.11$, on a scale of $1-5)$ and $86 \%$ of the respondents reported learning wikis in less than a couple of days, although $8 \%$ of the respondents reported 
that they did not know how to use wikis at the end of the semester. The students who took longer than a couple of days to learn wikis had significantly lower perceived initial wiki expertise than those who picked up the skills quickly $(1.52 \mathrm{vs} 2.53, \mathrm{t}=-4.52$, $\mathrm{p}<0.001$ ), and experienced greater difficulty accessing the Wikis (3.17 vs 3.86, $\mathrm{t}=-2.43$, $\mathrm{p}<0.05$, on a scale of $1-5)$.

Table 1c: Web 2.0 experience

\begin{tabular}{|l|c|c|c|c|c|c|}
\hline $\begin{array}{c}\text { Web 2.0 } \\
\text { technology }\end{array}$ & $\mathrm{n}(\mathrm{a})$ & $\%$ & $\begin{array}{c}\text { Years of using } \\
\text { Mean (S.D.) }\end{array}$ & $\begin{array}{c}\text { Frequency } \\
\text { of use (b) } \\
\text { Mean (S.D.) }\end{array}$ & $\begin{array}{c}\text { Familiarity } \\
\text { (b) } \\
\text { Mean (S.D.) }\end{array}$ & $\begin{array}{c}\text { Initial wiki } \\
\text { expertise (c) } \\
\text { Mean (S.D.) }\end{array}$ \\
\hline Facebook, MySpace & 190 & $93 \%$ & $2.45(1.51)$ & $3.55(1.35)$ & $3.79(1.11)$ & \\
\hline Blogs & 93 & $45 \%$ & $4.04(2.36)$ & $3.14(1.33)$ & $3.66(1.10)$ & \\
\hline Forums & 100 & $49 \%$ & $4.66(2.60)$ & $3.29(1.28)$ & $3.75(1.19)$ & \\
\hline Used wikis before? & 34 & $17 \%$ & & & & $2.39(1.17)$ \\
\hline
\end{tabular}

(a) $\mathrm{n}$ is the number of students who used the technology;

(b) Scale 1-5 from "Very little" to "A lot"; (c) Scale 1-5 from "Very poor" to "Very good".

Table 1d: Technology self-efficacy

\begin{tabular}{|l|c|c|}
\hline \multicolumn{1}{|c|}{ Student group } & $\mathrm{n}$ & $\begin{array}{c}\text { Technology self-efficacy (a) } \\
\text { Mean (S.D.) }\end{array}$ \\
\hline Local & 66 & $4.28(.69)$ \\
\hline International & 139 & $4.05(.73)$ \\
\hline Overall & 205 & $4.12(.73)$ \\
\hline (a) Scale 1-5 from “Very unconfident" to “Very confident". \\
\hline
\end{tabular}

Table 2: Stepwise regression on wiki usage

\begin{tabular}{|c|c|c|c|c|c|c|c|}
\hline & $\begin{array}{c}\text { End } \\
\text { section } \\
\text { wiki } \\
\text { expertise }\end{array}$ & $\begin{array}{l}\text { Frequency } \\
\text { of using } \\
\text { wiki for } \\
\text { assignment }\end{array}$ & \begin{tabular}{|c} 
Time spent \\
on \\
workshop \\
assignment
\end{tabular} & $\begin{array}{c}\text { Time spent } \\
\text { on case } \\
\text { study } \\
\text { assignment }\end{array}$ & $\begin{array}{c}\text { Time } \\
\text { spent to } \\
\text { add } \\
\text { contents }\end{array}$ & $\begin{array}{l}\text { Time } \\
\text { spent to } \\
\text { revise } \\
\text { contents }\end{array}$ & $\begin{array}{l}\text { Time } \\
\text { spent to } \\
\text { review } \\
\text { contents }\end{array}$ \\
\hline $\begin{array}{l}\text { Gender }(1= \\
\text { male; } 2 \text { = female })\end{array}$ & & $\begin{array}{l}-.28^{\star \star *} \\
(8.2 \%)\end{array}$ & $\begin{array}{l}0.19^{* *} \\
(2.5 \%)\end{array}$ & & & & \\
\hline $\begin{array}{l}\text { Status }(1=\text { inter- } \\
\text { national student; } \\
2=\text { local student }\end{array}$ & & & & & $\begin{array}{l}0.23^{\star *} \\
(4.7 \%)\end{array}$ & $\begin{array}{l}0.17^{*} \\
(3.2 \%)\end{array}$ & \\
\hline $\begin{array}{l}\text { Use wiki before? } \\
(1=\text { yes, } 0=\text { no })\end{array}$ & & & $\begin{array}{l}0.16^{*} \\
(3 \%)\end{array}$ & $\begin{array}{l}0.194^{* *} \\
(3.8 \%)\end{array}$ & & & \\
\hline $\begin{array}{l}\text { Wiki initial } \\
\text { expertise }\end{array}$ & $\begin{array}{l}0.44^{* * *} \\
(29.3 \%)\end{array}$ & $\begin{array}{l}0.29^{* * *} \\
(6.7 \%)\end{array}$ & & & $\begin{array}{l}0.16^{*} \\
(2.6 \%)\end{array}$ & $\begin{array}{l}0.14^{*} \\
(2 \%)\end{array}$ & $\begin{array}{l}0.18^{*} \\
(3 \%)\end{array}$ \\
\hline Wiki access & $\begin{array}{l}0.34^{* * *} \\
(12.4 \%)\end{array}$ & & & & & & \\
\hline $\begin{array}{l}\text { Technology self- } \\
\text { efficacy }\end{array}$ & $\begin{array}{c}0.15^{\star *} \\
(2 \%)\end{array}$ & & & & $\begin{array}{l}-0.20^{* *} \\
(2.7 \%)\end{array}$ & & \\
\hline $\begin{array}{l}\text { Tutor wiki } \\
\text { experience }\end{array}$ & & & $\begin{array}{l}-0.16 * \\
(1.9 \%)\end{array}$ & & & & \\
\hline $\begin{array}{l}\text { Tutor perception } \\
\text { toward wikis }\end{array}$ & & $\begin{array}{l}0.14^{*} \\
(2.1 \%)\end{array}$ & $\begin{array}{l}0.24^{\star *} \\
(3.1 \%)\end{array}$ & & $\begin{array}{l}0.15^{*} \\
(2.2 \%)\end{array}$ & & \\
\hline $\mathrm{R}^{2}$ & $43.8 \%$ & $17 \%$ & $10.5 \%$ & $3.8 \%$ & $12.2 \%$ & $5.2 \%$ & $3 \%$ \\
\hline
\end{tabular}

Note: numbers in parenthesis are $\mathrm{R}^{2}$ change; ${ }^{*} \mathrm{p}<0.05,{ }^{* *} \mathrm{p}<0.01,{ }^{* * *} \mathrm{p}<0.001$

Table 2 provides the stepwise regression results for the 'usage' dependent variables considered in this study. Only those independent variables which were significant in 
the final regression model are included in the table. Table 2 clearly shows that perceived initial Wiki expertise is significantly associated with respondents' perceived end of semester Wiki expertise, as well as their usage of Wiki in their assignments.

Local students spent more time adding or revising the contents of their wiki pages than international students. This finding is inconsistent with previous studies (Gerbic, 2005) where international students were found to make greater use of asynchronous technologies (such as wikis) in their group collaboration to help overcome language barriers. As $77.1 \%$ of international students had at least one year's study at the University, it is considered likely that language was less of an issue for these students. The tutors were also found to have some impacts on students' use of wikis, although this was minor. Technology self-efficacy had only a very minor impact on use.

Interestingly, despite most respondents doubted their ability to use wikis at the start of semester, their confidence had increased significantly by the end $(t=14.00, p<0.001)$. A comparison of results between users with and without wiki experience (Table 3) clearly shows that students can enhance their skills of using wikis through learning and indicates that past wiki experience is important for boosting confidence in using wikis for collaboration.

Table 3: Wiki expertise comparison between experienced and non-experienced wiki users

\begin{tabular}{|c|c|c|c|c|}
\hline Experience & $\mathrm{n}$ & $\begin{array}{l}\text { Initial wiki } \\
\text { expertise(a) }\end{array}$ & $\begin{array}{c}\text { End semester } \\
\text { wiki expertise(a) }\end{array}$ & t-value \\
\hline Used wikis before & 34 & $3.44(1.21)$ & $3.91(1.00)$ & $-2.48^{*}$ \\
\hline No wiki experience & 171 & $2.18(1.04)$ & $3.30(0.95)$ & $-14.80^{\star * *}$ \\
\hline t-value & & $6.29^{* * *}$ & $3.37^{* *}$ & \\
\hline
\end{tabular}

\section{Wiki usefulness}

Table 4 provides stepwise regression results for all perceived usefulness variables. The tutor's perception of wikis was the most important factor associated with respondents' perceived usefulness of the wikis, with classes taken by unenthusiastic tutors having markedly lower scores than those taken by enthusiastic tutors.

Respondents' perceived end of semester wiki expertise was the second most important factor in explaining their perceptions of the usefulness of the wikis. The time spent on each assignment was also important in respondents' perceptions of usefulness, especially for the case study assignment, with the more time spent reviewing content correlating closely with increased perceptions of usefulness. In addition, the ease of access to the wikis was significantly associated with respondents' perceived usefulness of wikis in their weekly workshop assignment, but not the case study. As the weekly workshop assignment was the first assignment to use wikis, it would appear that ease of access to the wikis is an important factor in the initial stages of use, as would be expected.

Interestingly, prior experience with Facebook or MySpace had a small, but significant negative impact, on their perceived usefulness of the wikis, such that the more they had used other Web 2.0 technologies, the less useful they found wikis. 
Table 4: Stepwise regression on perceived wiki usefulness

\begin{tabular}{|c|c|c|c|c|c|c|}
\hline & \begin{tabular}{|c|} 
Quick for \\
finishing \\
workshop \\
assignment
\end{tabular} & \begin{tabular}{|c|} 
Conven- \\
ience for \\
workshop \\
assignment
\end{tabular} & $\mid \begin{array}{l}\text { Quality for } \\
\text { workshop } \\
\text { assignment }\end{array}$ & $\begin{array}{c}\text { Quick for } \\
\text { finishing } \\
\text { case study } \\
\text { assignment }\end{array}$ & \begin{tabular}{|c} 
Conven- \\
ience for \\
case study \\
assignment
\end{tabular} & \begin{tabular}{|c|} 
Quality for \\
case study \\
assignment
\end{tabular} \\
\hline Status & & $\begin{array}{l}-0.17^{*} \\
(1.9 \%)\end{array}$ & & & & \\
\hline $\begin{array}{l}\text { FBE (Facebook or } \\
\text { MySpace experience) }\end{array}$ & $\begin{array}{l}-0.12^{*} \\
(1.3 \%)\end{array}$ & & $\begin{array}{l}-0.16^{* *} \\
(2.5 \%)\end{array}$ & $\begin{array}{l}-0.18^{* *} \\
(3.1 \%)\end{array}$ & $\begin{array}{l}-0.14^{*} \\
(1.9 \%)\end{array}$ & $\begin{array}{l}-0.17^{* *} \\
(2.9 \%)\end{array}$ \\
\hline $\begin{array}{l}\text { FOE (Forum } \\
\text { experience) }\end{array}$ & $\begin{array}{l}-0.14^{*} \\
(2.6 \%)\end{array}$ & & & & & \\
\hline Wiki access & $\begin{array}{l}0.21^{* *} \\
(2.5 \%)\end{array}$ & $\begin{array}{l}0.19^{* *} \\
(2.4 \%)\end{array}$ & $\begin{array}{l}0.16^{*} \\
(1.8 \%)\end{array}$ & & & \\
\hline $\begin{array}{l}\text { Tutor perception of } \\
\text { wikis }\end{array}$ & $\begin{array}{l}0.29^{\star * *} \\
(16.2 \%)\end{array}$ & $\begin{array}{l}0.27^{\star * *} \\
(13.4 \%)\end{array}$ & $\begin{array}{l}0.27^{* * *} \\
(14.2 \%)\end{array}$ & $\begin{array}{l}0.27^{* * *} \\
(8.1 \%)\end{array}$ & $\begin{array}{l}0.20^{* *} \\
(6.6 \%)\end{array}$ & $\begin{array}{l}0.23^{* * *} \\
(7.9 \%)\end{array}$ \\
\hline $\begin{array}{l}\text { End semester wiki } \\
\text { expertise }\end{array}$ & $\begin{array}{l}0.20^{* *} \\
(8.6 \%)\end{array}$ & $\begin{array}{c}0.23^{* *} \\
(7 \%)\end{array}$ & $\begin{array}{l}0.17^{*} \\
(8.4 \%)\end{array}$ & $\begin{array}{l}0.26^{* * *} \\
(12.7 \%)\end{array}$ & $\begin{array}{l}0.21 * * \\
(4.6 \%)\end{array}$ & $\begin{array}{l}0.22^{* * *} \\
(5.7 \%)\end{array}$ \\
\hline $\begin{array}{l}\text { Time spent on work- } \\
\text { shop assignment }\end{array}$ & $\begin{array}{l}0.14^{*} \\
(1.7 \%)\end{array}$ & & $\begin{array}{l}0.19^{* *} \\
(3.9 \%)\end{array}$ & & & \\
\hline $\begin{array}{l}\text { Time spent on case } \\
\text { study assignment }\end{array}$ & & & & $\begin{array}{l}0.26^{* * *} \\
(6.6 \%)\end{array}$ & $\begin{array}{l}0.22^{* *} \\
(10.8 \%)\end{array}$ & $\begin{array}{c}0.26^{* * *} \\
(3.7 \%)\end{array}$ \\
\hline $\begin{array}{l}\text { Time spent to revise } \\
\text { contents }\end{array}$ & & $\begin{array}{l}0.21^{* *} \\
(3.4 \%)\end{array}$ & $\begin{array}{l}0.12 * \\
(1.4 \%)\end{array}$ & & $\begin{array}{l}0.19^{* *} \\
(3.5 \%)\end{array}$ & $\begin{array}{l}0.23 * * * \\
(13.1 \%)\end{array}$ \\
\hline $\mathrm{R}^{2}$ & $32.9 \%$ & $28.1 \%$ & $32.2 \%$ & $30.5 \%$ & $27.5 \%$ & $33.3 \%$ \\
\hline
\end{tabular}

\section{Attitude towards wikis}

Table 5 shows stepwise regression results for all overall attitudes toward wiki variables.

Table 5: Stepwise regression on wiki attitudes

\begin{tabular}{|c|c|c|c|}
\hline & $\begin{array}{l}\text { Overall I } \\
\text { like wiki }\end{array}$ & $\begin{array}{c}\text { I will use wikis in } \\
\text { my other courses for } \\
\text { group collaboration }\end{array}$ & $\begin{array}{c}\text { I will use wikis } \\
\text { elsewhere }\end{array}$ \\
\hline Status & & $-0.19^{* * *}(2.7 \%)$ & \\
\hline FOE (Forum experience) & & $0.10^{*}(1 \%)$ & \\
\hline Use wiki before & & & $0.28^{\star * \star}(12.8 \%)$ \\
\hline Wiki initial expertise & & & $0.20^{* *}(2.9 \%)$ \\
\hline End semester wiki expertise & $0.22^{* * *}(5 \%)$ & $0.16^{* *}(2.7 \%)$ & \\
\hline Tutor wiki experience & & $0.12^{*}(1.3 \%)$ & $0.12^{*}(1.3 \%)$ \\
\hline Tutor perception toward wikis & $0.13^{* *}(1.3 \%)$ & & \\
\hline Quick for finishing workshop assignment & $0.16^{* *}(2.2 \%)$ & & \\
\hline Convenience for workshop assignment & & $0.27^{* * *}(3.5 \%)$ & \\
\hline Quality for workshop assignment & $\begin{array}{c}0.29^{* * *} \\
(46.8 \%)\end{array}$ & $0.22^{* *}(35 \%)$ & $0.27^{\star \star \star}(21.5 \%)$ \\
\hline Quick for finishing case study assignment & & $0.21^{\star \star}(5.7 \%)$ & $0.21^{* *}(3.7 \%)$ \\
\hline Convenience for case study assignment & $0.29^{* \star *}(8.9 \%)$ & & \\
\hline $\mathrm{R}^{2}$ & $64.1 \%$ & $51.9 \%$ & $42.2 \%$ \\
\hline
\end{tabular}


Three questions were used to evaluate students' 'end of semester' attitudes towards wikis. Overall, it would be fair to say that they did not like wikis ( $M=2.60$, out of 5) and did not see themselves using it in other courses $(M=2.36)$ or elsewhere $(M=2.31)$. Table 5 shows that respondents had a more positive attitude toward wikis if they believed that wikis would improve their workshop assignment quality. The extent to which wikis were seen as being quick and convenient in helping the students complete their assignments was also important in explaining the students' attitudes towards wikis. Although the tutors' perceptions toward wikis were not very significant in students' overall attitudes, it was indirectly reflected through perceived usefulness. It is interesting to find that respondents' experience of other technologies or their perceived technology self-efficacy was not important in influencing their attitudes toward wikis at the end of the semester.

\section{Discussion}

This study found that those students with past wiki experience, or enthusiastic tutors and who had easy access to wikis would use wikis in their collaboration, find it useful, and intend to use it in group collaboration in future courses. The findings raise a number of interesting points which are discussed below.

\section{The importance of prior experience and mandatory use}

The findings indicate that wikis are not a difficult tool to learn and even those students without any prior wiki experience can quickly pick it up and use it in group collaboration. Prior experience does however appear to provide a considerable advantage in how well wikis are used for group collaborative learning, suggesting that the earlier the students are exposed to wikis in their university careers, the better the outcomes in terms of group collaboration.

The lack of formal training at the beginning of the semester may account for some of the disparity in use, usefulness and the attitude towards wikis, as students without training or prior experience may have been more prone to getting into difficulties. According to the staff involved in the course, no formal training was provided at the start of the semester as it was assumed that wikis were easy to learn and informal training and supporting would be sufficient. This assumption may have been wrong as the informal training and support may have only assisted those students who were actively exploring and using the wiki. In hindsight, a training session at the start of the semester including security and formatting skills may have made a difference.

No factors were found to strongly influence students' use of wikis. As the use was mandatory for the weekly workshop assignments and the some of the case study assignment, this result is not unexpected and tallies with previous studies (e.g., Cole, 2009; Raitman, et al., 2005). Interestingly there was a drop off in the use of wikis in the later part of the case study assignment, for which wiki use was not mandatory (39\% vs. $45 \%$ using wikis for less than one hour per week). Students who reported higher levels of use in the case study assignment and continued to use wikis beyond the mandatory component $(76.5 \%$ of experienced users used more than one hour per week for case study assignment) and reported higher levels of usefulness with wikis for the assignment (with mean of 2.42 and 1.82 between experienced and non-experiences users respectively) tended to have prior experience with wikis, which suggests that there might be some form of threshold effect for use, experience and confidence, beyond which students begin to find it useful. 


\section{The importance of staff attitudes}

The tutors' perception about using wikis in the course was the key factor associated with students' rating of the usefulness of wikis in their assignments. This factor was particularly strong on the first assignment (the weekly assignment) and less so on the second (the case study).

Prior studies have shown that the encouragement and support that people gain from their supervisors or peers is important in determining how they perceive and use the technology being adopted (Piccoli, Ahmad \& Ives, 2001; Sun, Tsai, Finger, Chen \& Yeh, 2008; Webster \& Hackley, 1997). If the tutors displayed a negative attitude towards wikis then it would be expected that this attitude would influence their student's attitude (Eales, Hall \& Bannon, 2002). This would especially be the case at the start of the course as the students had little experience of wikis against which to gauge the veracity of their tutor's attitude. As student's confidence in using wikis increased through actual use on the first assignment, their own views should supplant those of their tutors, with their greater confidence reducing the need for support from the tutors and hence distancing the student from the tutor's poor attitude. Students whose confidence did not increase would have remained within the tutor's influence.

This finding suggests that the attitude and behaviour of staff is very influential, especially in the early use of the tool and that measures such as ensuring staff themselves are confident with the wikis are needed. The findings also reiterate the role of mandatory use in getting students to use the tool when first introduced.

\section{The importance of ongoing use}

The time spent on the assignments was also significantly associated with students' perceived wiki usefulness in their assignments, with the relationship between the time spent on the case study assignment and perceived wiki usefulness being much stronger than that for the weekly workshop assignment. At first glance these results suggest that the greater the time spent using wikis on the assignments, the better the students' skills become. The improvement in skills then leads to more proficient use of the tool which, in turn, results in improved perceptions of usefulness as they realise the tools potential. The difference between the two ratings for the two assignments does however appear to be a little more complicated, with two alternative explanations suggested by the results.

First, it can be argued that the time spent on the case study was more strongly related to perceived usefulness because use of wikis was not compulsory on the case study (except for a small component right at the start), and that if students made use of wikis on this assignment, beyond what was required, then they did so because they perceived wikis as being useful. Findings regarding the linkage between prior experience and usefulness would seem to support this explanation. The second possible reason may lie in the nature of the assignment tasks themselves. In the case study assignment the tasks were difficult to be divided between the group members, thus generating a real need to actually collaborate to complete the assignment and thus making the use of wikis to support this collaboration an attractive option. The workshop assignment tasks were readily sub-dividable, with less need for collaboration and less need for wiki's support in this regard, resulting in lower perceived usefulness. The technology-task fit model (Goodhue \& Thompson, 1995) may provide some further insight into this explanation. A lack of granularity in the 
measures captured regarding students' expectations of group collaboration and how group collaborative learning processes actually happened makes this a point for further research.

\section{The impact of experience with other technologies}

Prior studies have found that past experience with technologies has a positive impact on the use and perceived usefulness of new technologies (Venkatesh, Morris, Davis \& Davis, 2003). This study's findings however indicate quite the opposite as students' experience of using Facebook or MySpace had a small, but significant, negative impact on the perceived usefulness of wikis in collaboration on the assignments. It would appear that the more experience a student had with Facebook or MySpace, the less they found wikis useful. One possible explanation is that the "Net Generation" students have, through use of technologies such as Facebook, developed high expectations as to how Internet technologies should look and operate. Compared to technologies such as Facebook or MySpace, the wiki implemented in the course was quite rudimentary and not particularly user friendly and was criticised by students for being too plain, not as easy to use as Microsoft Word, lacking the ability to attach photos or pictures and not supporting real time chat. Controlling for this influence may simply be a matter of setting expectations concerning how the technology operates. It also suggests that wikis with more user friendly features would be preferable.

Interestingly, students' perceived technology self-efficacy, which was very high (Mean=4.12, on a scale of 1 to 5), appears to have very little to do with their perceptions of wiki's usefulness in their assignments and contradicts past studies' findings (Venkatesh, et al., 2003). One possible explanation is that current students are much more technologically savvy and confident in their ability to learn new technologies than previous cohorts.

\section{Future use depends on usefulness}

The findings indicate that those students who benefited most from using wikis in their weekly workshop assignments liked wiki the most and were willing to use wikis for other group collaboration. This result is also associated with mandatory use of wikis for workshop assignments, with those students who worked out how best to use wikis quickly were able to move onto effective collaboration within the timeframe of the weekly workshop assignments. Those groups whose uptake of wiki was slower were unable to reach sufficient capability to put wikis to effective use. The reasons why some groups may have developed good use habits more quickly than others could be due to a range of reasons, including those discussed above, or could simply be that some groups began their assignments earlier than others which led to a more positive attitude towards wikis that persisted throughout the course. Unfortunately the data does not allow this to be investigated, but it does suggest that a range of factors needs to be attended to if wikis are to be used on an ongoing basis.

\section{Implications}

\section{Implications for research}

This study has a number of important contributions to the research effort investigating the use of technology in education, especially in regard to Web 2.0 technologies. First, the study demonstrates the importance of teacher's attitudes toward technology on 
students' technology perceptions and intentions for future use. Although previous TAM-based studies included this variable under various guises, such as social influence (Fulk, Schmitz \& Steinfield, 1990), subjective norms (van Raaij \& Schepers, 2008), or instructor attitudes (Sun, et al., 2008), none of these studies found teachers' attitudes toward technology as one of the primary factors in influencing students' perceptions and intentions. For instance, van Raaij and Schepers (2008) found that the opinions of course instructors only indirectly influenced students' system usage, via perceived usefulness. They characterised it as a gradual internalisation process which became less salient over time (Venkatesh \& Davis, 2000). This study's findings indicate that instructors' opinions are far more important in forming students' attitudes toward technologies, especially at early adoption stage, suggesting that this variable needs to be addressed when investigating the adoption and use of technology in the classroom.

Second, this study found a more accurate, realistic and less circumspect relationship between the perceived usefulness of a technology and intentions for further use of that technology, by measuring students' post-use perceptions of usefulness of wikis in learning. Most TAM-based studies measure a participant's perceived usefulness of IT based on their pre-acceptance attitudes toward technology, which were derived from media, advertising, or others (Lee, 2010). Compared to users' first hand experience, second hand information about technology usefulness may be biased. Lee (2010) also found that after-use attitude toward technology (referred to as satisfaction by Lee) was a stronger predictor of continuance intention than pre-use attitude. Future research could measure perceived usefulness toward technology after its actual use in order to obtain a more robust relationship between perceptions and intention to use in the future.

Third, actual usage may not be a good indicator of users' perceived usefulness and intention to use in the future, especially when use of the technology is mandatory. Although prior studies have shown that people who spent more time on the technology-mediated learning systems were more likely to be satisfied with such experience and more likely to use them again in the future (e.g., Hiltz, 1994), the findings of this study show that usage was not a significant factor associated with students' satisfaction and intention to use in the future, when compared to tutor's attitude toward wikis and users' perceived confidence of using wikis. Future research in which the use of the technology being studied is mandatory may need to be cautious when including technology usage as one of the key variables.

Finally, the results of this study suggest that the task-technology fit model (Goodhue \& Thompson, 1995) in the technology mediated educational environment may be worth pursuing as an explanation of the interaction between the wikis and the task in which they are used. As Lund and Smordal (2006) indicate, not all tasks are suited to collective and distributed settings. Even though this study did not measure the fit between wikis and the assignment tasks explicitly, it was found that wikis were more suitable for tasks which required collaboration than for those that required only cooperation. Further research that explicitly measures the collaborative learning process and draws on the task-technology fit model would seem to be a worthwhile next step in understanding the use and usefulness of wikis in group collaboration.

\section{Implications for practice}

This study has a number of implications for practice. First, instructors must be made keenly aware that the attitudes they bring to the classroom about the technology to be 
used can have a significant impact on the student's uptake and perceptions of that technology. Instructors should understand why the technology is being used in the course and how such technology can enhance students' learning. Without such an understanding, it would be difficult for instructors to show their enthusiasm for using the technology to their students (Tsinakos, 2006).

Second, even though this study found instructors' attitudes to be very significant in influencing their students' perceptions and continuance intention, their skills in using the technology are still nonetheless important. If instructors have sound knowledge of using the technology to be adopted, supporting the students in the use of that technology, especially in the early stages of use, will be easier. This study found that the quality of the technical support by the tutors at the start of the course was a very influential factor on students' perceptions and intention to use in the future. In hindsight it should not have been a surprise that negative sentiment arose in the course as it did, because when things went wrong, the instructors did not have the necessary skills to fix the problems quickly and efficiently (Reinhold \& Abawi, 2006). It would seem important therefore that all instructors have the necessary skills to be able to support the tool being used to the extent of being able to handle most routine issues and, as has been found in prior studies (e.g., Raman, et al., 2005; Ramanau \& Geng, 2009), instructors will need training to acquire such skills. It would also seem important that those responsible for training staff in the use of new technologies raise the issue of the impact of staff attitude on student perceptions of the technology and the importance of maintaining a positive attitude towards the technology in which they are instructing their students.

Third, students also require training in the technologies that they will use in their learning (Raman, et al., 2005). Ideally such training should happen as early as possible and should be comprehensive. The training should be well thought through and properly tested well in advance, as a trouble free introduction to the technology is important (Raman, et al., 2005). Students' IT skills should not be overestimated simply because they belong to the "Net Generation" (Ramanau \& Geng, 2009) or are familiar with other Web 2.0 technologies. Where the use of Wikis is mandatory, sufficient initial training is essential (Duffy \& Bruns, 2006; Ramanau \& Geng, 2009).

Fourth, if technologies such as wikis are to be used throughout a student's education, then the technology should be introduced as early as possible in the students' university career. This will help the students build their confidence and positive attitude toward the technology, which should assist in promoting future use. Consistent with prior studies, this study also showed that tutor's perceptions would have less of an impact on those students with more experience in using wikis (van Raaij \& Schepers, 2008; Venkatesh \& Davis, 2000).

Fifth, instructors should be aware that using technology for group collaboration is not just about deploying a collaborative tool for a task. According to Lund and Smordal (2006) and O'Neil, Chuang and Chung (2003), enhanced group learning outcomes are achieved with technologies where tasks are designed so they cannot be readily subdivided and group collaboration is genuinely required. Such task design also encourages students to participate and to take responsibility, ownership, and control of their own learning processes (Eales, et al., 2002; Jones \& Issroff, 2005). One way to achieve this goal is to assign a specific role to each group member in order to meet group assignment requirements (O'Neil, et al., 2003). De Pedro et al. (2006) suggest the 
role of "Editor in chief" for group assignments in order to ensure periodic work upon restructuring and synthesising of the collective information.

Sixth and lastly, instructors should choose a technology which has been proven, via rigorous, real life testing, to be easy to deploy, learn, use and support. The current students have grown up with the Internet and computers and simply expect information technology to work. Failure to meet these expectations can very quickly lead to poor outcomes.

\section{Limitations}

A number of limitations are evident in this study. First, as using wikis in the assignment groups for the purpose of collaboration was mandatory, caution needs to be taken when generalising findings of this study to other settings where using technology is voluntary.

Second, tutors' data were measured with one-item questions and gathered from a third party, rather than from the tutors themselves. It was considered important to have this data to examine the impact of tutors on students' perceptions and use of wikis. Future studies may wish to collect tutor's perceptions toward wikis, tutor's teaching experience and technology skills to examine the instructors' perspective of the use and usefulness of wikis in teaching.

Third, data was collected from 205 of the 289 students enrolled in the course. The other 84 students were absent in the final tutorial and, as such, excluded from the data collection. Such absence may bias the results. However, it is believed that those students not included in the study were not different, as a group, from those who completed the survey.

Fourth, one-item questions were used to measure technology experience, use, and future use attitudes variables as it was considered important to keep the time taken to complete the survey to a minimum (and hence enhance the response rates (Edwards, et al., 2002)). As a result, there may have been a trade-off between internal validity and response rate or even the quality of answers. Although past research indicates that this is a common method for measuring easy to understand and less equivocal variables, such as the ones we used in this study (Scott \& Rockwell, 1997), additional evidence with multi-item scales validated by previous studies could enhance internal validity. In addition, design constraints of the wikis used meant that the time spent using the wikis on the assignments could not objectively measured. The self-reported data provided in the surveys cannot be verified and may be biased. A future study may choose a wiki which provides actual usage data, thus enriching analysis.

\section{Conclusions}

This study aimed to identify and understand the factors that influenced the use, usefulness and intention to use in the future, of wikis in collaborative group assignments. Through the investigation of the deployment of wikis in an introductory information systems course via a questionnaire survey of over $70 \%$ of the students in the course, it was found that the level of use of the wikis is influenced by the students' level of experience and expertise with wikis, with more experienced wiki users making greater use of wikis for group collaboration. 
The most important factor influencing a student's perception is the attitude of their tutor towards wikis, with those students of tutors with negative attitudes towards the use of wikis in the course having markedly lower ratings of wiki's usefulness. This influence does however appear to be somewhat moderated by the student's level of expertise with wikis. The extent to which the students found wikis useful is itself the major influence over their intention to use wikis in the future.

Interestingly, a number of factors found to be important in other studies, such as selfefficacy regarding the learning of computer applications and prior experience with similar types of applications, appear to have little or no impact in the case of wikis.

With the rapid uptake of wikis in learning, future research on identifying students' motivations for using wikis is highly desirable as such understanding would help instructors accommodate students' needs in technology-mediated teaching environments. Furthermore, the ultimate goal of using technologies in teaching is to enhance students' learning outcomes. Although research shows positive associations between subjective and objective learning outcome measures (Wall, et al., 2004), future research should examine whether using wikis (or other technologies) can help students enhance their learning outcomes by not only asking about their perceptions, but also measuring their learning performance objectively.

There is no doubt that information technologies do, and will continue to, play a significant role in group collaboration and this study is an initial step in documenting how wikis are being used for this purpose. The results of this study support Elgort et al.'s (2008) argument that using wikis does not guarantee that group collaboration will happen or that group learning outcomes will be enhanced. The effective implementation and use of wikis to enhance group collaboration depends on the alignment of many factors: choosing the right technology, designing a suitable group task, making use mandatory, train instructors and students, and maintaining a positive attitude towards Wikis among the staff involved in the course.

\section{References}

Ahmad, T. B. T., Basha, K. M., Marzuki, A. M., Hisham, N. A. \& Sahari, M. (2010). Faculty's acceptance of computer based technology: Cross-validation of an extended model. Australasian Journal of Educational Technology, 26(2), 268-279. http: / / www.ascilite.org.au/ajet/ajet26/ahmad.html

Alavi, M. (1994). Computer-mediated collaborative learning: An empirical evaluation. MIS Quarterly, 18(2), 159-174.

Bandura, A. (1986). Social foundations of thought and action: A social cognitive theory. Englewood Cliffs, NJ: Prentice-Hall.

Bruns, A. \& Humphreys, S. (2005). Wikis in teaching and assessment: The M/Cyclopedia project. In International Wiki Symposium, 16-18 Oct. 2005, San Diego. http: / / eprints.qut.edu.au/2289/1/2289.pdf

Bullock, D. (2004). Moving from theory to practice: An examination of the factors that preservice teachers encounter as they attempt to gain experience teaching with technology during field placement experience. Journal of Technology and Teacher Education, 12(2), 211-237.

Chickering, A. W. \& Gamson, Z. F. (1987). Seven principles for good practice in undergraduate education. AAHE Bulletin, 39(7), 3-7. [verified 5 Apr 2011] http: / / learningcommons.evergreen.edu / pdf/ fall1987.pdf 
Choy, S. O. \& Ng, K. C. (2007). Implementing wiki software for supplementing online learning. Australasian Journal of Educational Technology, 23(2), 209-226. http:/ / www.ascilite.org.au/ajet/ajet23/choy.html

Cole, M. (2009). Using wiki technology to support student engagement: Lessons from the trenches. Computers \& Education, 52, 141-146.

Compeau, D. R. \& Higgins, C. A. (1995). Computer self-efficacy: Development of a measure and initial test. MIS Quarterly, 19(2), 189-211.

Davis, F. D. (1989). Perceived usefulness, perceived ease of use, and user acceptance of information technology. MIS Quarterly, 13(3), 319-339.

de Pedro, X., Rieradevall, M., López, P., Sant, D., Piñol, J., Núñez, L., et al. (2006). Writing documents collaboratively in higher education using traditional vs. wiki methodology (I): Qualitative results from a 2-year project study. Paper presented at the 4th International Congress of University Teaching and Innovation. [verified 5 Apr 2011] http: / / uniwiki.ourproject.org/ dl93

Dempster, A. P., Laird, N. M. \& Rubin, D. B. (1977). Maximum likelihood from incomplete data via the EM algorithm. Journal of the Royal Statistical Society Ser. B, 39, 1-38.

Dewiyanti, S., Brand-Gruwel, S., Jochems, W. \& Broers, N. J. (2007). Students' experiences with collaborative learning in asynchronous computer-supported collaborative learning environments. Computers in Human Behavior, 23, 496-514.

Dillenbourg, P., Baker, M., Balye, A. \& O'Malley, C. (1996). The evolution of research on collaborative learning. In E.Spada \& P.Reiman (Eds.), Learning in humans and machine: Towards an interdisciplinary learning science (pp. 189-211). Oxford: Elsevier.

Duffy, P. \& Bruns, A. (2006). The use of blogs, wikis and RSS in education: A conversation of possibilities. Paper presented at the Online Learning and Teaching Conference, Brisbane. http: / / eprints.qut.edu.au/5398/1/5398.pdf

Eales, R. T. J., Hall, T. \& Bannon, L. J. (2002). The motivation is the message: Comparing CSCL in different settings. In CSCL '02 Proceedings of the Conference on Computer Support for Collaborative Learning: Foundations for a CSCL Community. ACM.

Edwards, P., Roberts, I., Clarke, M., DiGuiseppi, C., Pratap, S., Wentz, R., et al. (2002). Increasing response rates to postal questionnaires: Systematic review. British Medical Journal, 324, 11831191. [verified 5 Apr 2011] http:/ / www.bmj.com/ content/324/7347/1183.full

Elgort, I. (2007). Using wikis as a learning tool in higher education. In ICT: Providing choices for learners and learning. Proceedings ascilite Singapore 2007.

http: / / www.ascilite.org.au/conferences/ singapore07/procs/elgort.pdf

Elgort, I., Smith, A. G. \& Toland, J. (2008). Is wiki an effective platform for group course work? Australasian Journal of Educational Technology, 24(2), 195-210. http: / / www.ascilite.org.au/ajet/ajet24/elgort.html

Fulk, J. (1993). Social construction of communication technology. Academy of Management Journal, 36(5), 921-950.

Fulk, J., Schmitz, J. \& Steinfield, C. W. (1990). A social influence model of technology use. In J. Fulk \& C. Steinfield (Eds.), Organizational and communication technology (pp. 117-142). Newbury Park, CA: Sage Publications.

Fulk, J., Steinfield, C. W., Schmitz, J. \& Power, J. G. (1987). A social information processing model of media use in organizations. Communication Research, 14(5), 529-552.

Gefen, D., \& Straub, D. W. (1997). Gender differences in the perception and use of e-mail: An extension to the Technology Acceptance. MIS Quarterly, 21(4), 389-390. 
Gerbic, P. (2005). Chinese learners and computer mediated communication: Balancing culture, technology and pedagogy. In Balance, fidelity, momentum: Proceedings ASCILITE Brisbane 2005. http: / / www.ascilite.org.au/conferences/brisbane05/blogs/proceedings/27_Gerbic.pdf

Goodhue, D. L. \& Thompson, R. L. (1995). Task-technology fit and individual performance. MIS Quarterly, 19(2), 213-236.

Gribbins, M. L., Hadidi, R., Urbaczewski, A. \& Vician, C. (2007). Technology-enhanced learning in blended learning environments: A report on standard practices. Communications of the Association for Information Systems, 20, 741-759.

Guo, Z. \& D'Ambra, J. (2009). The influence of national and organizational cultures on technology use: An exploratory study within a multinational organizational setting. Journal of Global Information Management, 17(4), 74-94.

Guo, Z., Tan, F. B., Turner, T. \& Xu, H. (2008). An exploratory investigation into Instant Messaging preferences in two distinct cultures. IEEE Transactions on Professional Communication, 51(4), 396-415.

Guo, Z., Zhang, Y. \& Stevens, K. (2009). A 'uses and gratifications' approach to understanding the role of wiki technology in enhancing teaching and learning outcomes. Paper presented at the 17th European Conference on Information Systems, June, Italy, 2009. [verified 5 Apr 2011] http: / / aisel.aisnet.org / cgi / viewcontent.cgi?article=1021\&context=ecis2009

Hiltz, S. (1994). The virtual classroom: Learning without limits via computer networks. Norwood, NJ: Ablex.

Hiltz, S., Coppola, N., Rotter, N., Turoff, M. \& Benbunan-Fich, R.. (2000). Measuring the importance of collaborative learning for the effectiveness of ALN: A multi-measure, multimethod approach. Journal of Asynchronous Learning Networks, 4(2). [verified 22 Apr 2011] http: / / sloanconsortium.org/sites/default/ files/v4n2_hiltz_1.pdf

Jones, A. \& Issroff, K. (2005). Learning technologies: Affective and social issues in computersupported collaborative learning. Computers $\mathcal{E}$ Education, 44, 395-408.

Jones, P. (2007). When a wiki is the way: Exploring the use of a wiki in a constructively aligned learning design. In ICT: Providing choices for learners and learning. Proceedings ascilite Singapore 2007. http: / / www.ascilite.org.au/conferences/ singapore07/procs/jones-p.pdf

Kersaint, G., Horton, B., Stohl, H. \& Garofalo, J. (2003). Technology beliefs and practices of mathematics education faculty. Journal of Technology and Teacher Education, 11(4), 549-577.

King, R. C. \& Xia, W. D. (1997). Media appropriateness - effects of experience on communication media choice. Decision Sciences, 28(4), 877-910.

Lamb, B. (2004). Wide open spaces: Wikis, ready or not. EDUCAUSE Review, 39(5), 36-48. http: / / www.educause.edu/EDUCAUSE+Review / EDUCAUSEReviewMagazineVolume39/ WideOpenSpacesWikisReadyorNot/157925

Lee, M.-C. (2010). Explaining and predicting users' continuance intention toward e-learning: An extension of the expectation-confirmation model. Computers $\mathcal{E}$ Education, 54(2), 506-516.

Leuf, B. \& Cunningham, W. (2001). The wiki way: Quick collaboration on the web. Addison-Wesley.

Lund, A. \& Smordal, O. (2006). Is there a space for the teacher in a Wiki? Paper presented at the WikiSym 2006. [verified 6 Apr 2011]

http: / / citeseerx.ist.psu.edu / viewdoc/ download?doi=10.1.1.102.4063\&rep=rep1\&type=pdf

Malani, P. \& Dwyer, C. (2005). Low cost collaborative tools to support student teams. Paper presented at the Proceedings of Students/Faculty Research Day, Pace University. [verified 6 Apr 2011] http: / / csis.pace.edu / ctappert/srd2005/a1.pdf

McCreadiea, M. \& Rice, R. E. (1999). Trends in analyzing access to information. Part I: crossdisciplinary conceptualizations of access. Information Processing $\mathcal{E}$ Management, 35(1), 45-76. 
McMullin, B. (2005). Putting the learning back into learning technology. In G. O'Neill, S. Moore \& B. McMullin (Eds.), Practice of university learning and teaching. Dublin: AISHE. [verified 6 Apr 2011] http: / / www.aishe.org/ readings / 2005-1/ mcmullin-D01-M10-2004.html

Nachmias, R., Mioduser, D., \& Shemla, A. (2000). Internet usage by students in an Israeli high school. Journal of Educational Computing Research, 22(1), 55-73.

O'Neil, H. F., Chuang, S.-H. \& Chung, G. K. W. K. (2003). Issues in the computer-based assessment of collaborative problem solving. Assessment in Education: Principles, Policy $\mathcal{E}$ Practice, 10(3), 361-373.

Parker, K. R. \& Chao, J. T. (2007). Wiki as a teaching tool. Interdisciplinary Journal of Knowledge and Learning Objects, 3, 57-72.

Piccoli, G., Ahmad, R. \& Ives, B. (2001). Web-based virtual learning environments: A research framework and a preliminary assessment of effectiveness in basic IT skills training. MIS Quarterly, 25(4), 401-426.

Raitman, R., Augar, N. \& Zhou, W. (2005). Employing wikis for online collaboration in the elearning environment: Case study. Paper presented at the Third International Conference on Information Technology and Applications.

Raman, M., Ryan, T. \& Olfman, L. (2005). Designing knowledge management system for teaching and learning with wiki technology. Journal of Information Systems Education, 16(3), 311-320.

Ramanau, R. \& Geng, F. (2009). Researching the use of Wikis to facilitate group work. Procedia Social and Behavioral Sciences, 1, 2620-2626. [verified 6Apr 2011] http:/ / oro.open.ac.uk/27433/

Reinhold, S. \& Abawi, D. F. (2006). Concepts for extending wiki systems to supplement collaborative learning. Lecture Notes in Computer Sciences (Vol. 3942, pp. 755-767). Springer: Berlin / Heidelberg.

Rice, R. E. (1993). Media appropriateness: Using social presence theory to compare traditional and new organizational media. Human Communication Research, 19(4), 451-484.

Rice, R. E. \& Aydin, C. (1991). Attitudes toward new organizational technology: Network proximity as a mechanism for social information processing. Administrative Science Quarterly, $36,219-244$.

Rice, R. E. \& Shook, D. E. (1988). Access to, usage of , and outcomes from an electronic messaging systems. ACM Transactions on Office Information Systems, 6(3), 255-276.

Rice, R. E. \& Webster, J. (2002). Adoption, diffusion and use of new media in organizational settings. In D. Akin \& C. Lin (Eds.), Communication technology and society (pp. 191-227). Cresskill, NJ: Hampton Press.

Roschelle, J. \& Teasley, S. D. (1995). The construction of shared knowledge in collaborative problem solving. In C. E. O'Malley (Ed.), Computer supported collaborative learning (pp. 169197). Heidelberg: Springer-Verlag. [verified 6 Apr 2011, 2.5 MB] http: / / tecfa.unige.ch/tecfa/publicat/dil-papers-2/cscl.pdf

Schaffert, S., Bischof, D., Burger, T., Gruber, A., Hilzensauer, W. \& Schaffert, Sandra. (2006). Learning with semantic wikis. Paper presented at the First Workshop on Semantic Wikis-From Wiki to Semantics.

Scott, C. R. \& Rockwell, S. C. (1997). The effect of communication, writing, and technology apprehension on likelihood to use new communication technologies. Communication Education, 46(1), 44-60.

So, H.-J., \& Brush, T. A. (2008). Student perceptions of collaborative learning, social presence and satisfaction in a blended learning environment: Relationship and critical factors. Computers $\mathcal{E}$ Education, 51, 318-336. 
Stahl, G., Koschmann, T. \& Suthers, D. (2006). Computer-supported collaborative learning: An historical perspective. In Group cognition: Computer support for building collaborative knowledge (pp. 409-426). Cambridge, UK: Cambridge University Press.

Sun, P.-C., Tsai, R. J., Finger, G., Chen, Y.-Y. \& Yeh, D. (2008). What drives a successful elearning? An empirical investigation of the critical factors influencing learner satisfaction. Computers E Education, 50(4), 1183-1202.

Tsai, P.-S., Tsai, C.-C. \& Hwang, G.-H. (2010). Elementary school students' attitudes and selfefficacy of using PDAs in a ubiquitous learning context. Australasian Journal of Educational Technology, 26(3), 297-308. http:/ / www.ascilite.org.au/ajet/ajet26/tsai.html

Tsinakos, A. A. (2006). Collaborative student modelling: A new perspective using Wiki. WSEAS Transactions on Advances in Engineering Education, 3(6), 475-481. [verified 6 Apr 2011] http: / / de.teikav.edu.gr/tsinakos/pdf/TRANS_tsinakos.pdf

van Raaij, E. M. \& Schepers, J. J. L. (2008). The acceptance and use of a virtual learning environment in China. Computers $\mathcal{E}$ Education, 50(3), 838-852.

Venkatesh, V. \& Davis, F. D. (2000). A theoretical extension of the technology acceptance model: Four longitudinal field studies. Management Science, 46(2), 186-204.

Venkatesh, V., Morris, M. G., Davis, G. B. \& Davis, F. D. (2003). User acceptance of information technology: Toward a unified view. MIS Quarterly, 27(3), 425-478.

Wall, T. D., Michie, J., Patterson, M., Wood, S. J., Sheehan, M., Clegg, C. W., et al. (2004). On the validity of subjective measurs of company performance. Personnel Psychology, 57, 95-118.

Watson, D. M. (1998). Blame the technocentric artifact! What research tells us about problems inhibiting teacher use of IT. In G. Marshall \& M. Ruohonen (Eds.), Capacity building for IT in education in developing countries (pp. 185-192). London: Chapman \& Hall.

Webster, J. \& Hackley, P. (1997). Teaching effectiveness in tchnology-mediated distance learning. Academy of Management, 40(6), 1282-1309.

Xu, L. (2007). Project the wiki way: Using wiki for computer science course project management. Paper presented at the Consortium for Computer Sciences in Colleges.

Zhang, Y. (2005). Age, gender, and Internet attitudes among employees in the business world. Computers in Human Behavior, 21(1), 1-10.

Authors: Zixiu Guo, Senior Lecturer
School of Information, Management and Technology
The University of New South Wales, Sydney NSW 2052, Australia
Email: z.guo@unsw.edu.au
Kenneth John Stevens, Lecturer
School of Information, Management and Technology
The University of New South Wales, Sydney NSW 2052, Australia
Email: k.stevens@unsw.edu.au
Please cite as: Guo, Z. \& Stevens, K. J. (2011). Factors influencing perceived usefulness
of wikis for group collaborative learning by first year students. Australasian Journal of
Educational Technology, 27(2), 221-242.
http: / / www.ascilite.org.au/ajet/ajet27/guo.html

